\title{
Exoelectrogenic anaerobic granular sludge for simultaneous electricity generation and
} wastewater treatment

\author{
Zhao, Nannan; Treu, Laura; Angelidaki, Irini; Zhang, Yifeng
}

Published in:

Environmental Science and Technology

Link to article, DOI:

10.1021/acs.est.9b03395

Publication date:

2019

Document Version

Peer reviewed version

Link back to DTU Orbit

Citation (APA):

Zhao, N., Treu, L., Angelidaki, I., \& Zhang, Y. (2019). Exoelectrogenic anaerobic granular sludge for simultaneous electricity generation and wastewater treatment. Environmental Science and Technology, 53(20), 12130-12140. https://doi.org/10.1021/acs.est.9b03395

\section{General rights}

Copyright and moral rights for the publications made accessible in the public portal are retained by the authors and/or other copyright owners and it is a condition of accessing publications that users recognise and abide by the legal requirements associated with these rights.

- Users may download and print one copy of any publication from the public portal for the purpose of private study or research.

- You may not further distribute the material or use it for any profit-making activity or commercial gain

- You may freely distribute the URL identifying the publication in the public portal 


\section{Energy and the Environment}

\section{Exoelectrogenic anaerobic granular sludge for simultaneous electricity generation and wastewater treatment

\author{
Nannan Zhao, Laura Treu, Irini Angelidaki, and Yifeng Zhang
}

Environ. Sci. Technol., Just Accepted Manuscript • DOI: 10.1021/acs.est.9b03395 • Publication Date (Web): 11 Sep 2019

Downloaded from pubs.acs.org on September 11, 2019

\section{Just Accepted}

"Just Accepted" manuscripts have been peer-reviewed and accepted for publication. They are posted online prior to technical editing, formatting for publication and author proofing. The American Chemical Society provides "Just Accepted" as a service to the research community to expedite the dissemination of scientific material as soon as possible after acceptance. "Just Accepted" manuscripts appear in full in PDF format accompanied by an HTML abstract. "Just Accepted" manuscripts have been fully peer reviewed, but should not be considered the official version of record. They are citable by the Digital Object Identifier (DOI®). "Just Accepted" is an optional service offered to authors. Therefore, the "Just Accepted" Web site may not include all articles that will be published in the journal. After a manuscript is technically edited and formatted, it will be removed from the "Just Accepted" Web site and published as an ASAP article. Note that technical editing may introduce minor changes to the manuscript text and/or graphics which could affect content, and all legal disclaimers and ethical guidelines that apply to the journal pertain. ACS cannot be held responsible for errors or consequences arising from the use of information contained in these "Just Accepted" manuscripts. 


\section{Exoelectrogenic anaerobic granular sludge}

\section{2 for simultaneous electricity generation and}

\section{3 wastewater treatment}

$4 \quad$ Nannan Zhao ${ }^{1,2}$, Laura Treul', Irini Angelidaki ${ }^{1}$, Yifeng Zhang ${ }^{1 *}$

$5{ }^{1}$ Department of Environmental Engineering, Technical University of Denmark, DK-2800

6 Lyngby, Denmark.

$7 \quad{ }^{2}$ College of Life Sciences, Zhejiang Sci-Tech University, 310018 Hangzhou, PR China.

*Corresponding author, Tel.: +45 45251410; fax: +45 45932850.

E-mail address: yifz@env.dtu.dk; yifzmfc@gmail.com (Yifeng Zhang) 


\section{Abstract}

18 Thick and electroactive biofilm is the key for successful development of microbial

19 electrochemical technologies and systems (METs). In this study, intact anaerobic granular

20 sludge (AGS), which are spherical and dense microbial associations, was successfully

21 demonstrated as novel and efficient biocatalysts in METs such as microbial fuel cell

22 (MFC). Three different strategies were explored to shift the microbial composition of AGS

23 from methanogenic into exoelectrogenic microbes, including varying external resistance,

24 organic loading, and manipulating anode potential. Among other strategies, only with

25 positive anode potential, AGS was successfully shifted from methanogenic to

26 exoelectrogenic conditions, as indicated by the significantly high current response (10.32

$27 \mathrm{~A} / \mathrm{m}^{2}$ ) and $100 \%$ removal of organic carbon from wastewater. Moreover, AGS bioanode

28 showed no significant decrease in current generation and organic removal at $\mathrm{pH}$,

29 indicating good tolerance of AGS to acidic conditions. Finally, 16S rRNA sequencing

30 revealed the enrichment of exoelectrogens and inhibition of methanogens in the microbial

31 community of AGS after anode potential control. This study provides a proof-in-concept

32 of extracting electrical energy from organic wastes by exoelectrogenic AGS along with

33 simultaneous wastewater treatment, and meanwhile opens up a new paradigm to create

34 efficient and cost-effective exoelectrogenic biocatalyst for boosting the industrial

35 application of METs.

36 Keywords: Anaerobic granular sludge; Exoelectrogenic biocatalyst; Electric energy; 16S

37 rRNA analysis; Wastewater treatment. 


\section{Introduction}

40 Growing concerns over the intensive energy consumption for conventional wastewater

41 treatment technologies has boosted interest in the development of energy-neutral treatment

42 technologies ${ }^{1}$. Microbial electrochemical technologies and systems (METs) has shown

43 promising potential in several applications spanning from renewable electricity production

44 to biochemical and bioproducts production by using the electrons derived from waste

45 organic matters by bacteria to perform dedicated reduction reaction ${ }^{2-4}$. Though promising,

46 MFC technologies are still encountering a long-standing challenge to develop thick and

47 efficient electroactive biofilm on the anode electrode. On the one hand, the limited biomass

48 content and retention in biofilm would lead to the low capacity for organic carbon removal

49 compared to conventional biotechnologies, and thus, extra post-treatment processes are

50 always required ${ }^{5,6}$, which would greatly increase the operational and maintenance cost. On

51 the other hand, MFC reactors which rely on thin anodic biofilm can't produce substantial

52 quantities of power to offset the practical energy demands for wastewater treatment ${ }^{7,8}$.

53 Thus, the conventional ways of fabricating electroactive biocatalysts (as biofilm) on the

54 anode do limit the wide application of MFC technology for wastewater treatment and 55 energy generation ${ }^{6,9}$.

56 In the past decades, anaerobic granular sludge (AGS), as aggregates of microorganism, is

57 popular among anaerobic biocatalysts for simultaneous bioenergy production (i.e., biogas

58 through anaerobic digestion) and wastewater treatment, due to its high organic removal

59 capacity and good tolerance to extreme conditions (e.g., toxic compounds and acidic

60 shocks $)^{10-12}$. In a previous MFC study ${ }^{13}$, homogeneous bacterial suspension, derived from

61 grinded AGS using a mortar and pestle followed by filtration (0.25-mm pore size sieve), 
62 has even been demonstrated as efficient inoculum for cultivating anodic biofilm. Thus,

63 AGS could be a potential habitat of exoelectrogenic bacteria, in addition to methanogens.

64 More recently, it has been found that the whole microbial aggregates can be electroactive

65 if direct interspecies electron transfer occurs among the diverse microbial consortia ${ }^{14,15}$.

66 Considering the essential properties of AGS with dense microbes, special channel

67 morphology and potential conductivity, it is reasonable to hypothesize that intact AGS

68 could function as an effective biocatalyst for an MFC if electroactive bacteria are enriched

69 inside of granule. To date, intact AGS has never been tested as electroactive biocatalyst in

70 the field of METs. Integration of intact AGS into anode could address the key challenge of

71 MFC and greatly boost its capacity for electricity generation and wastewater treatment.

72 Such combination could further strength the advantages of MFC over conventional

73 anaerobic treatment processes, in addition to the inherent merits of mild operating

74 conditions, high removal and energy efficiency for low strength wastewater, and easy use

75 and transport of end product (electricity in this case) ${ }^{16,17}$.

76 In this context, switching intact AGS from methanogenic to exoelectrogenic is a key to

77 achieve a successful integration. Thus, in this study, intact AGS was for the first time

78 manipulated and explored as biocatalyst in MFC for wastewater treatment and

79 bioelectricity generation. Several strategies to transform the intact AGS from

80 methanogenic to exoelectrogenic, were employed, and the outcomes were evaluated in

81 terms of organic removal, current response, and coulombic efficiency. Finally, the

82 microbial dynamics during manipulation of anode potential and microbial composition at

83 different sites of anode electrode were analyzed. To the best of our knowledge, it is the first

84 time to investigate the feasibility of tailoring intact granular sludge as biocatalyst for 
85 bioelectricity generation, which offers new insights in development of viable and

86 sustainable technology for cost-effective and efficient wastewater treatment.

\section{$87 \quad$ Materials and methods}

\section{$88 \quad$ MFC set up}

89 An MFC, made of nonconductive polycarbonate plates was constructed. The anode and

90 cathode chambers with the same dimension size $(4 \times 5 \times 5 \mathrm{~cm})$ were separated by a cation

91 exchange membrane (CEM, CMI 7000, Membrane international, NJ). Rubbers and screws

92 were used to tighten the reactor to avoid leakage. The anode electrode was made of a carbon

93 fiber brush wound into two twisted titanium wires $(5.0 \mathrm{~cm}$ diameter, $5.0 \mathrm{~cm}$ length, Mill-

94 Rose, USA), which were heated at $450{ }^{\circ} \mathrm{C}$ for 15 minutes before use as reported

95 previously $^{18}$. A reference electrode of $\mathrm{Ag} / \mathrm{AgCl}$ electrode $(+0.197 \mathrm{~V}$ vs SHE$)$ was placed

$96 \sim 0.3 \mathrm{~cm}$ close to the anode for accurate control of anode potential. The anodic chamber

97 was filled with $80 \mathrm{~g}$ wet AGS, which was collected from a mesophilic upflow anaerobic

98 sludge blanket reactor fed with potato wastewater (Colsen, Netherland). A stainless-steel

99 mesh was used to avoid the washing out of AGS and possible blocking issues. The total

100 volume of anode chamber was $100 \mathrm{ml}$, while the working volume was $50 \mathrm{ml}$. An external

101 recirculation bottle (filled with $500 \mathrm{ml}$ synthetic wastewater) was connected to anode

102 chamber with a recirculation flow rate of $50 \mathrm{ml} / \mathrm{min}$. To maintain a sufficient mixing, the

103 recirculation bottle was stirred at $400 \mathrm{rpm}$. A titanium woven wire mesh $(4 \times 4 \mathrm{~cm}, 0.15 \mathrm{~mm}$

104 aperture, William Gregor Limited, London) coated with $0.5 \mathrm{mg} / \mathrm{cm}^{2} \mathrm{Pt}$ was used as cathode

105 electrode. In closed circuit, the anode and cathode electrodes were connected through an

106 external resistance (1000 $\Omega$, unless otherwise stated). During anode potential control by 
107 potentiostat (Ivium-n-Stat, Ivium Technologies, Eindhoven, The Netherlands), three-

108 electrode cell mode was adopted; anode as working electrode, cathode as counter electrode

109 and $\mathrm{Ag} / \mathrm{AgCl}$ as reference electrode.

\section{Inoculation and operational strategies}

111 AGS was directly used as the inoculum for MFC start-up. The synthetic wastewater

112 contained (in $\mathrm{g} / \mathrm{L}$ of distilled water): sodium acetate, 1 (unless otherwise stated); $\mathrm{NH}_{4} \mathrm{Cl}$,

$113 \quad 0.31 ; \mathrm{NaH}_{2} \mathrm{PO}_{4} \cdot \mathrm{H}_{2} \mathrm{O}, 2.69 ; \mathrm{Na}_{2} \mathrm{HPO}_{4}, 4.33 ; \mathrm{KCl}, 0.13 ; 12.5 \mathrm{ml}$ mineral solution and 12.5

$114 \mathrm{ml}$ vitamin solution as described before ${ }^{19}$. The final $\mathrm{pH}$ of synthetic wastewater always

115 kept $7.0 \pm 0.2$. The anode chamber and external bottle was filled with the aforementioned

116 synthetic wastewater, reaching a total volume of $550 \mathrm{ml}$. The cathode chamber was filled

117 with $100 \mathrm{ml}$ ferricyanide solution $(50 \mathrm{mM}, \mathrm{pH}$ 7) to exclude the instability of cathodic

118 reaction. The catholyte was $50 \mathrm{mM}$ phosphate buffer solution containing $50 \mathrm{mM}$

119 ferricyanide.

120 Multiple reactors including duplicate set-ups have been operated for the tests according to

121 different purposes. Three strategies were employed successively in the same reactor. As

122 summarized in Table S1 in supporting information, strategy 1 referred to the effect of

123 external resistance on MFC performance under closed circuit. During strategy 1 operation,

124 the sodium acetate concentration was controlled at $1500 \mathrm{mg} / \mathrm{L}$. Thereafter, the influence of

125 different organic loading (1000, 1500 and $3000 \mathrm{mg} / \mathrm{L})$ on system performance was

126 evaluated in strategy 2 , during which the resistance was selected as $10 \Omega$. Subsequently, in

127 strategy 3, MFC was connected to the potentiostat and chronoamperometry measurement

128 was used to control anode potential at $+20 \mathrm{mV}$ (VS $\mathrm{Ag} / \mathrm{AgCl}$ ). During strategy 3, the 
129 sodium acetate level was $1000 \mathrm{mg} / \mathrm{L}$. Sequentially, to evaluate the persistence of positive

130 effect by controlling anode potential, MFC was connected in a closed circuit with $10 \Omega$

131 resistance, and fed with $1000 \mathrm{mg} / \mathrm{L}$ sodium acetate. Afterwards, the AGS were removed

132 out of the anode chamber to evaluate the functions of AGS, denoted as Control 1. The

133 cultivated AGS were transferred into another identical MFC with a completely new anode

134 to explore the current generation of the removed AGS, denoted as Control 2. The

135 transferring process was performed in an anaerobic box. The operational parameters (1000

$136 \mathrm{mg} / \mathrm{L}$ sodium acetate and $10 \Omega$ resistance) were employed for Control 1 and Control 2. At

137 the end, to evaluate the robust resistance to low $\mathrm{pH}$ conditions, same AGS were placed

138 back to the anode chamber and operated under different initial wastewater $\mathrm{pH}$ varying from

1395 to 7 . For comparison of AGS powered MFC with conventional MFC inoculated with

140 domestic wastewater, one set of MFC reactors with same configuration was constructed

141 (Control 3) and inoculated with domestic wastewater obtained from primary clarifier at

142 Lundtofte Wastewater Treatment Plant (Lyngby, Denmark). For all the reactors, at the

143 beginning of each batch, anode chamber and recirculation bottle was flushed with pure $\mathrm{N}_{2}$

144 for 10 minutes to keep anaerobic conditions.

\section{Analytical methods and calculations}

146 During strategy 1 and 2, the voltage across an external resistance was recorded by a digital

147 multimeter (model 2700, Keithley Instruments, Inc.; Cleveland, OH) every 30 minutes.

148 Current was calculated according to ohm's law ( $\mathrm{I}=\mathrm{U} / \mathrm{R})$. Current density was normalized

149 by the projected cathode area $\left(16 \mathrm{~cm}^{2}\right)$. During strategy 3 , the current response was

150 recorded by the potentiostat every $1 \mathrm{~min}$. Coulombic efficiency (CE) was calculated as 
$151 C E=\frac{C t}{C t h} \times 100 \%$, where $C_{t}$ was the total coulombs calculated by integrating current

152 response with time, calculated as $C_{t}=\int I d t, C_{t h}$ was the theoretical amount of coulombs

153 based on the COD degradation, calculated as $C_{t h}=\frac{F b \triangle C O D}{M}$, where $\mathrm{F}$ is Faraday's

154 constant $\left(96485 \mathrm{C} \mathrm{mol}^{-1} \mathrm{e}^{-}\right), \mathrm{b}$ is 4 referring to the transferred electrons per mole of oxygen,

$155 \mathrm{M}$ is 32 representing the molecular weights of oxygen, $\triangle C O D$ is the removed COD amounts

156 (unit gram $)^{20}$.

157 Total chemical oxygen demand (TCOD) was measured according to the standard method

158 (APHA, 1999). COD removal rates were fitted assuming a first-order kinetic reaction with

159 respect to substrate concentrations, and calculated according to the following equation:

$$
\operatorname{Ln} \frac{C O D_{t}}{C O D_{0}}=-k t \quad \mathrm{Eq}(1)
$$

161 where $C O D_{0}$ is the initial COD concentration, $C O D_{t}$ is the COD concentration at time t, 162 and $\mathrm{k}$ is the first-order kinetic rate coefficient. The coefficient $\mathrm{k}$ at varied $\mathrm{pH}$ was calculated 163 and compared in section 3.2, in order to distinguish the optimal $\mathrm{pH}$ regarding to the fastest 164 carbon utilization.

165 Acetate was measured via a GC with FID detection (Agilent 6890). The sample pH was 166 immediately measured by using A PHM 210 pH meter (Radiometer). Produced gas was 167 collected by connecting a gasbag to the headspace of recirculation bottle. The volume was 168 measured by a $100 \mathrm{ml}$ syringe. $\mathrm{CO}_{2}$ and $\mathrm{CH}_{4}$ were analyzed by a GC-TCD fitted with 169 paralleled column of $1.1 \mathrm{~m} \times 3 / 16$ 'Molsieve 137 and $0.7 \mathrm{~m} \times 1 / 4$ ' with $\mathrm{H}_{2}$ as the carrier 170 gas (MGC 82-12, Microlab A/S, Denmark), and $\mathrm{H}_{2}$ was determined by a GC-TCD fitted 
171 with a $4.5 \mathrm{~m} \times 3 \mathrm{mms}-\mathrm{m}$ stainless column packed with Molsieve SA (10/80), as previously

172 described ${ }^{21}$.

173 Mastersizer 2000 (Malvern Instruments, UK) was employed to measure the particle size

174 distribution of the raw AGS and cultivated AGS after strategy 3. Scanning electron

175 microscopy (SEM - FEI Quanta 200 ESEM FEG equipped with energy dispersion

176 spectroscopy, EDS - Oxford) was used for the observation of AGS morphology. For

177 morphological characterization, the raw AGS and AGS after strategy 3 were sampled,

178 washed with phosphorus buffer solution (50 mM, pH 7) and fixed by soaking into 4\%

179 formaldehyde for 24 hours at $4{ }^{\circ} \mathrm{C}$. Subsequently, the samples were washed by gradient

$18025 \%, 50 \%, 75 \%, 90 \%, 95 \%$, and $100 \%$ ethanol/distilled water solutions successively.

181 Afterwards, samples were freeze-dried for overnight to get the powder specimens. The 182 specimens were coated with a gold thin layer (Quorum sputter coater, UK) and observed 183 by SEM-EDS at $3.0 \mathrm{kV}$.

\section{Microbial community analysis}

185 To characterize changes in microbial community before and after operation, the raw 186 granules, and the enriched granules and anodic biofilm after strategy 3 were all collected 187 by using sterilized scalpel or spoon as previously described ${ }^{22}$. Granules were sampled at 188 either in the direct vicinity, or further away from the anode. All the samples were collected 189 in triplicate except the biofilm which was sampled in duplicate. Total DNA extraction was 190 performed using PowerSoil DNA Isolation Kit (MoBio PowerSoil, Carlsbad, CA, USA).

191 Total genomic DNA amplification using universal primers 515F/806R was conducted on 
192 V4 hypervariable region of 16S rRNA gene, and amplicons were sequenced by Illumina

193 MiSeq desktop sequencer (Ramaciotti Centre for Genomics, Kensington, Australia).

194 Raw data was deposited in the Sequence Read Archive database

195 (https://www.ncbi.nlm.nih.gov/sra) under the accession number PRJNA485399. OTU

196 clustering and taxonomy identification were performed using microbial genomics module

197 plug of CLC Workbench software (V.8.0.2, QIAGEN) as previously described ${ }^{23}$. OTU was

198 chosen to represent the Alpha diversity, while Principal Component Analysis (PCA)

199 performed by STAMP software ${ }^{24}$ was selected to represent Beta diversity. The taxonomical

200 assignments of the selected interesting OTUs (relative abundance over $0.5 \%$ ) was

201 performed including a manual comparison of CLC results with 16S ribosomal RNA

202 sequences (Bacteria and Archaea) database at the National Center for Biotechnology

203 Information (NCBI) by using $\mathrm{BLAST}^{23}$. Microbial relative abundance and folds change

204 were visualized in heat maps using Multi experiment viewer software (MeV 4.9.0).

205 Statistics regarding to the significant differences in microbial communities were identified

206 by t-test in STAMP software.

207 Results and discussion

208 Different strategies to enhance the electroactivity of AGS for bioelectricity generation

209 and wastewater treatment

$210 \quad$ Impact of external resistance

211 Figure 1 is here. 
212 The strategy of varying external resistance was first applied to the MFC reactor inoculated

213 with AGS. The current density, as representative of electricity generation, showed a

214 different behavior with different resistances (Figure 1A). When external resistance was

215 changed from 1000 to $10 \Omega, 14$ fold increase of maximum current density (from 0.41 to

$\left.2165.84 \mathrm{~A} / \mathrm{m}^{2}\right)$ was observed at the same acetate level $(1500 \mathrm{mg} / \mathrm{L})$. The trend of current

217 generation at different external resistances was consistent with previous studies ${ }^{25}, 26$.

218 During the same period (Figure 1B), The COD removal was greatly improved (from $67 \%$

219 to $87 \%$ ) when MFC was switched from 1000 to $10 \Omega$. The higher COD removal rate at 10

$220 \Omega$ indicated that the substrate oxidation rate was enhanced when subjected to lower

221 resistance. Regarding to the biogas production rate and methane yield, it was noticeable

222 that the methane production was significantly increased at $10 \Omega$ (Figure $1 \mathrm{C}$ ). The result

223 showed that the increase of COD removal after changing resistance to $10 \Omega$ was partly due

224 to the anaerobic methanation. The results were different from the previous studies that

225 methanogens activity was inhibited at lower resistance ${ }^{27-29}$. In this study, the AGS was

226 originally cultivated for biomethanation which was different from previous MFC studies.

227 In addition, decreasing external resistance could be an effective way to enrich

228 exoelectrogens, but it may also facilitate interspecies electron transfer between

229 exoelectrogens and methanogens as reported previously ${ }^{30}$. There was no significant

230 difference in anodic potential (around $-500 \mathrm{mV}$ ) and $\mathrm{pH}$ (approx. $\mathrm{pH}$ 7) during the

231 operation with two different external resistances (data not shown). The influence of $\mathrm{pH}$ in

232 the methanogenic activity could be neglected. Thus, strategy 1 referred to changing

233 resistance was not an effective way to inhibit methanogenic activity. Considering the

234 enhanced electricity production, R-10 $\Omega$ was selected for the following experiments. 


\section{Impact of substrate concentration}

236 According to the previous study ${ }^{31}$, the methanogens activity could be manipulated by

237 organic loading. Therefore, as strategy 2, the acetate concentrations ranging over 1000,

2381500 and $3000 \mathrm{mg} / \mathrm{L}$ was applied consecutively. As shown in Figure 1A, the current

239 response significantly decreased when the acetate concentration increased from 1000 to

2401500 or $3000 \mathrm{mg} / \mathrm{L}$. It suggested the exoelectrogens weren't activated by elevated organic

241 loading. The electricity production was inhibited by increasing organic loading, as the

242 current density at $1000 \mathrm{mg} / \mathrm{L}$ was the highest among all conditions. From the COD removal

243 performance, it was clearly observed that COD removal rate was greatly enhanced with

244 elevated acetate concentrations. The average COD removal rate for 1000, 1500 and 3000

$245 \mathrm{mg} / \mathrm{L}$ was $70.99,110.59$ and $360.60 \mathrm{mg} / \mathrm{L} / \mathrm{d}$, respectively. The COD removal was probably

246 contributed by (1) acetate oxidation by exoelectrogens; (2) acetate oxidation by

247 methanogens; (3) acetate oxidation by aerobic microbes. On one hand, from the

248 aforementioned current response (Figure 1A), it was clearly observed that current density

249 didn't increase dramatically with increasing of organic loading, which indicated that the

250 contribution of exoelectrogens to acetate oxidation wasn't enhanced with improved carbon

251 loading. On the other hand, due to the anolyte was flashed with nitrogen gas before starting

252 each test, the contribution by aerobic oxidation could be limited. Thus, the only possible

253 reason would be due to the activity of methanogens. To confirm our speculation, the biogas

254 production rate and methane yield were further analysed. As depicted in Figure 1C, the

255 higher acetate concentration, the faster methane production rate was observed, suggesting

256 the active methanogenesis process at elevated acetate concentration. Also, the methane

257 yield increased accordingly, which indicated the unsuccessful inhibition of methanogens 
258 activity by improving organic loading. It was noticeable that in all cases, methane contents

259 always kept almost ten times higher than carbon dioxide. This could be due to its high

260 solubility of $\mathrm{CO}_{2}$. Recirculation of liquid was applied in the anode, which may promote the

261 dissolution of $\mathrm{CO}_{2}$. Overall, the above results demonstrated that the acetate concentration

262 of $1000 \mathrm{mg} / \mathrm{L}$ was good to obtain a superior electricity generation, and the substrate

263 concentration was not the contributing for turning methanogenic AGS into electrogenic.

\section{Impact of anodic potential}

265 Figure 2 is here.

266 In addition to external resistance and organic loading, the anode potential has been reported

267 to impact microbial community structure and electrochemical performance ${ }^{29,32}$. Therefore,

268 controlling anode potential at $+20 \mathrm{mV}$ ( $\mathrm{VS} \mathrm{Ag} / \mathrm{AgCl}$ ) as the third strategy was employed.

269 Clearly, during the period of anode potential control, the acetate was degraded rapidly in 5

270 days (Figure 2B). In fact, after 3 days, the acetate concentration already decreased from

271800 to $33 \mathrm{mg} / \mathrm{L}$, resulting in $96 \%$ removal. Correspondingly, the peak current density

272 increased significantly to $10.32 \mathrm{~A} / \mathrm{m}^{2}$ (Figure $2 \mathrm{~A}$ ). The high current response with fast

273 acetate degradation indicated that anode potential motivated the exoelectrogenic reactions

274 other than methanogenic. On the one hand, positive anode potential meant more energy to

275 support electroactive bacterial growth. It was reported that at relatively higher anode

276 potential, exoelectrogens can theoretically gain more energy for their growth and

277 maintenance ${ }^{33,34}$, according to:

$$
\Delta G^{0^{\prime}}=-n F\left(\text { Eanode }-E_{\text {donor }}^{0^{\prime}}\right)
$$


279 where $\Delta G^{0^{\prime}}$ is the Gibbs free energy change at standard conditions ( $\mathrm{pH} 7$ and $25^{\circ} \mathrm{C}$ ), $\mathrm{n}$ is 280 the number of electrons transferred, $\mathrm{F}$ is Faraday's constant $\left(96485 \mathrm{C} \mathrm{mol}^{-1} \mathrm{e}^{-}\right), E_{\text {anode }}$ is

281 the anode potential, $E_{\text {donor }}^{0^{\prime}}$ is the standard biological redox potential of electron donor. On 282 the other hand, positive anode potential may affect the electron transfer kinetics and attract 283 bacteria to move towards the electrode to form a thick biofilm ${ }^{35}$. Therefore, when the anode 284 potential was increased from $-550 \mathrm{mV}$ (measured anode potential at closed-circuit) to +20

$285 \mathrm{mV}$, both of the carbon removal and current generation were greatly enhanced. To confirm 286 the inhibited methanogenic activity at high anode potential, biogas production rate and 287 methane yield were analysed. As shown in Figure 2C, methane yield almost decreased to 288 0, which indicated that the methanogenic activity was fully suppressed at high anode 289 potential. Furthermore, it was reported that the amounts of proteins (i.e. OmcA), which are 290 responsible for extracellular electron transfer, increased with elevating anodic potential ${ }^{35}$. 291 More direct electron transfer-related protein at positive potential helped to stimulate an 292 electroactive-biofilm formation ${ }^{35}$.

293 To examine the persistence of this strategy for electroactive bacteria enrichment, the 294 reactor was subsequently switched to MFC mode (without potential control) again. It was 295 shown that the peak current density increased from 3.30 (before potential control) to 6.41 $296 \mathrm{~A} / \mathrm{m}^{2}$ (after potential control) when it was fed with $1000 \mathrm{mg} / \mathrm{L}$ acetate (Figure $2 \mathrm{~A}$ ). The 297 acetate removal efficiency increased from $50 \%$ (9 days) to $100 \%$ ( 8 days), indicating 298 effectiveness of anode potential control on enrichment of exoelectrogens. The $\mathrm{pH}$ was quite 299 stable (around $\mathrm{pH} 7$ during each batch run, data not shown) before and after potential 300 control. The contribution of capacitive effect to the high current generation after potential 301 control could be neglected, since the maximum stable current generation lasted for a few 
302 hours while discharging behaviour is normally around few seconds to minutes. To further 303 explore the contribution of AGS in electricity generation and carbon removal, the 304 performance of both MFC after removing AGS from anode chamber (Control 1) and new

305 MFC anode with removed AGS (Control 2) were investigated, respectively. In control 1, 306 the peak current density immediately decreased from 6.59 to $0.52 \mathrm{~A} / \mathrm{m}^{2}$, suggesting that

307 the AGS was partially involved in electron transfer. Accordingly, the acetate concentration 308 decreased from 731 to $166 \mathrm{mg} / \mathrm{L}$ after 7 days, resulting in $77 \%$ acetate removal. Since no 309 methane was produced in control 1, the contribution of methanogens to acetate removal

310 could be excluded. The current response and carbon removal observed in control 1 could

311 be due to small amount of residual AGS on anode since it is impossible to remove all AGS

312 from the anode. As shown in Figure S1, a completely new anode with cultivated AGS

313 produced a maximum current density of $1.11 \mathrm{~A} / \mathrm{m}^{2}$ after 1 day, which was higher than

314 control 1. But it didn't recover to the level observed before moving. The results of two 315 controls indicated that both AGS and formed biofilm on electrode played a

316 vital/cooperative role for the current generation. Even the AGS was exoelectrogenic, the

317 last step of electron transfer from bulk solution to solid electrode may still require an 318 electroactive biofilm as electron conduit.

319 To short conclude, the above results indicated that anode potential controlled at $+20 \mathrm{mV}$ is

320 effective to facilitate electroactive species growth and electron transfer in AGS.

321 Methanogens are well known strict anaerobes i.e. they require very low potential to grow

$322(<-300 \mathrm{mV})$. Therefore, exoelectrogens could dominate and got exclusively the chance to 323 use acetate as substrate. 


\section{Acid resistance}

$325 \quad$ Figure 3 is here.

326 In the previous studies, the most common inoculum for MFC electroactive biofilm

327 enrichment was domestic wastewater, which was either attached on anode or suspended in

328 liquid $^{36,37}$. Comparatively, the AGS with diverse microbes and intrinsic granular structure

329 was used as inoculum in our work. It was previously reported that wastewater $\mathrm{pH}$ would

330 significantly affect MFC performance ${ }^{29}$. Thus, in this section, the effect of $\mathrm{pH}$ shock on the

331 electrogenic capacity of the enriched AGS anode was investigated. Figure S2 depicts

332 acetate removal rates which showed good agreement with the current output at different

$333 \mathrm{pH}$ ranging over 5 to 7 (Figure S2). The maximum current density at each condition was

334 shown in Figure 3. The highest maximum current density $\left(5.21 \mathrm{~A} / \mathrm{m}^{2}\right)$ was observed at $\mathrm{pH}$

3357 in AGS-MFC. When $\mathrm{pH}$ was decreased from 7 to 5 , the ability of electron production

336 was significantly deteriorated for both reactors. It was reported that exoelectrogens

337 couldn't survive in the acidic environment when $\mathrm{pH}$ was lower than $5.5^{38}$. Although both

338 of reactors were negatively affected by the acid $\mathrm{pH}$, AGS-MFC showed a relatively

339 stronger resistance to low $\mathrm{pH}$ compared to typical MFC inoculated with wastewater.

340 Assuming first-order kinetics, the rate coefficient was calculated according to Eq. (1), as

341 displayed in Figure 3. In both reactors, the rate coefficient showed a similar trend to $\mathrm{pH}$

342 variations. The highest rate of $0.35 \mathrm{~d}^{-1}$ was obtained at $\mathrm{pH} 7$ in AGS-MFC. In AGS-MFC,

343 when $\mathrm{pH}$ was decreased from 7 to 5, the rate coefficient decreased correspondingly from

3440.35 to $0.20 \mathrm{~d}^{-1}$, indicating diminished substrate degradation at acidic environment.

345 Similarly, for control MFC, the rate coefficient decreased from 0.20 to $0.12 \mathrm{~d}^{-1}$. The rate

346 coefficient at $\mathrm{pH} 5$ in AGS-MFC was even close to the value of control reactor at $\mathrm{pH}$, 
347 meaning a superior performance of acetate oxidative reaction in AGS-MFC even at

348 unfavourable $\mathrm{pH}$ conditions. Clearly, neutral $\mathrm{pH}$ conditions proved to be the optimal

349 environment for the exoelectrogenic bacteria. AGS inoculated MFC would have better

350 resistance considering that the biofilm from AGS might become even thicker during long-

351 term operation.

\section{Morphological characteristics and elemental composition of AGS}

353 Figure 4 is here.

354 The morphological image of single AGS taken after strategy 3 was depicted in Figure 4.

355 As shown in Figure 4A, an AGS has a spherical rough surface and macroporous carbon

356 architecture. A zoomed in image of the surface is shown in Figure 4B, in which the entire

357 surface of AGS was covered with compact rod-shaped bacterial cells. The porous structure

358 and rough surface would be beneficial for microbial growth and biofilm formation ${ }^{39}$. In

359 addition to the excellent porous structure, granules exhibit good mechanical strength for

360 microbes to resist the changes of surrounded environments (such as extreme $\mathrm{pH}$ or organic

361 loading shock) compared to the conventional flocs or biofilm ${ }^{12,40}$. High-resolution of SEM

362 images of AGS channels (Figure 4C) demonstrated deep channels of ca. 1 um diameter,

363 with rod-shaped bacteria aligned on the channel sides. It revealed that the bacterial cells

364 were densely adhered not only to AGS surface, but also interior sections of AGS, indicating

365 the porous structure of AGS permitted sufficient substrate exchange from outside to inside

366 to support internal biofilm growth ${ }^{41}$. All of these attractive properties (the porous structure,

367 rough surface and dense microbes) enabled AGS as an ideal inoculum candidate for MFC

368 exoelectrogens enrichment. 
369 According to the EDS results (Figure 4D), the raw AGS contained high levels of carbon

$370(53 \%)$ and oxygen (32\%), and small amounts of minerals such as silicon, calcium and other

371 traditional metals including iron. These minerals were reported as the main skeleton of

372 granular structure, and may be involved in the electrical double layer formation of AGS as

373 reported before ${ }^{42,43}$. After strategy 3, the cultivated AGS contained higher amounts of

374 carbon, which could be assigned to the increasing biomass contents. The low deviation

375 suggested a homogeneous mineralized granular structure. To get further information of the

376 granule size, Mastersizer 2000 was used to measure the particle size distribution (Figure

377 4E). It was found the mean diameter based on the volume weighted was significantly

378 increased from 122 (raw AGS) to $760 \mu$ m (cultivated AGS). It means over 50\% granules

379 had the diameter of $760 \mu \mathrm{m}$ after anode potential control. The bigger size demonstrated

380 that granulation of AGS was enhanced after being shifted from methanogenic to

381 electrogenic condition ${ }^{44}$. This is also consistent with the higher energy gain of bacteria at

382 higher anodic potential which would inevitably result in higher cell biomass.

\section{The influence of anode potential manipulation in microbial community dynamics}

384 After the selection and comparison of three strategies, strategy 3 (anode potential) was

385 demonstrated to be the most effective to inhibit methane production and improve current

386 generation. To gain an insight into microbial communities residing in granules and in

387 biofilm of carbon brush, 16S rRNA gene analysis was employed.

388 According to alpha diversity results shown in Figure S3 (Supporting Information), an

389 increase in microbial diversity (represented as OTU) regardless of sampling position was

390 observed after potential control. The results indicate that a more diverse microbiome was 
391 enriched after a positive anode potential. Beta diversity shown in Figure S4A demonstrated

392 a distinct microbial dynamic change before and after anode potential control. A dramatic

393 change was found between raw granules and enriched granules/biofilms after strategy 3

394 based on the principal percentage (PC1 and PC2) (Figure S4A). When taking further 395 analysis of PC3, AGS taken from different positions (close and far from anode) were also

396 different from each other in microbial community compositions. Same distinct difference

397 was observed between granules and anodic biofilm. The above results were in agreement

398 with previous findings that the anode potential significantly affected the microbiome

399 clustering in anode ${ }^{34}$.

$400 \quad$ Figure 5 is here.

401 High throughput 16S RNA amplicon sequencing was used to analyze the microbial 402 dynamics in AGS and attached anodic biofilm, and the relative abundance of taxa over $0.5 \%$

403 is illustrated in Figure 5A. The vast majority of raw AGS microbial community was

404 composed of $90 \%$ bacteria (based on the average relative abundance). Bacteroidetes (23\%), 405 Firmicutes (23\%), Proteobacteria (12\%), followed by Synergistetes (9\%), and others 406 (23\%), were the most dominant phyla (Figure S5). The microbial composition in raw AGS 407 was in agreement of common mesophilic AGS as reported before ${ }^{45}$. Bacteroidetes, 408 Firmicutes and Proteobacteria has always been detected in MFC, which were supposed to 409 be responsible for electricity generation ${ }^{32,}{ }^{46}$. Thus, the raw AGS probably already 410 contained electroactive bacteria in the innate microbial community, which could enable its 411 utilization as biocatalyst in an MFC.

412 To get an insight into how the microbial community composition in MFC, the changes 413 between the raw and enriched AGS after manipulating anode potential were compared. The 
414 results are shown in Figure 5B. As illustrated, in a cluster of taxa (Figure 5B, Group 1),

415 increasing significantly in relative abundance after manipulating anode potential was

416 mainly composed by exoelectrogenic bacteria. For example, Synergistaceae spp. (5 and 6)

417 increased from $0.2 \%$ to over $10 \%$ of relative abundance in both the granules and biofilm,

418 indicating that the proliferation of species belonging to Synergistaceae was due to the

419 improved anode potential. The family Synergistaceae was often found in MFC anode ${ }^{47}$. It

420 was noticeable that the strain of Arcobacter butzleri spp. (16 and 8), known as

421 exoelectrogens ${ }^{48}$, appeared after the potential control (accounting for $6.5 \%$ of relative

422 abundance in the biofilm sample), strongly supported the enrichment of exoelectrogens.

423 Also, Desulfurmonadales spp. appeared after improving anode potential, suggesting a

424 strong correlation to the potential change. The Desulfurmonadales spp. (22 and 65) showed

425 a 97\% similarity to Pelobacter propionicus and Geobacter chapellei. Pelobacter

426 propionicus was known as propionate producer from acetate, while no propionate was

427 detected during the experiment. Therefore, the high similarity of the strain was very likely

428 affiliated to Geobacter chapellei, which was reported as Fe(III) reducer ${ }^{49}$. Since iron-

429 reducing bacteria are known to use electrode as electron acceptor, we deduce that

430 Desulfurmonadales spp. represented by Geobacter chapellei may also have been involved

431 in direct electron transfer to anode ${ }^{35}$. Furthermore, the strain affiliated to the family

432 Marinilabiliaceae also increased in abundance, which has been previously found in MFC

433 bioanode ${ }^{50}$. Interestingly, another known species Methanobacterium beijingense was

434 dominant after improving anode potential. M. beijingense was known as hydrogenotrophic

435 methanogens using $\mathrm{H}_{2} / \mathrm{CO}_{2}{ }^{51}$. However, since no methane was detected, the species might

436 contribute mainly to maintain the granular structure by acting as the nucleation center, as 
437 described elsewhere ${ }^{52}$. It has to be mentioned that although the enrichment of 438 exoelectrogens was demonstrated at positive anodic potential, the microbial community 439 was different from the previous findings. The predominance of Geobacter species was 440 typically reported for the acetate-fed $\mathrm{MFCs}^{53}$, 54, while in this study, the microbial 441 community was more diverse with relatively fewer numbers of Geobacter. It was mainly 442 due to the different inoculum sources ${ }^{53}$, 55. In this study, methanogenic AGS was used as 443 the inoculum, while the domestic wastewater was often reported as the inoculum when 444 Geobacter was the most abundant in the acetate-fed exoelectrogenic biofilms.

445 Comparatively, a cluster of taxa decreased significantly in relative abundance, which 446 demonstrated that the transition from low anode potential $(-550 \mathrm{mV})$ to high anode 447 potential $(+20 \mathrm{mV})$ created a hostile habitat to these taxa. More specifically, Mesotoga 448 infera, which was involved in the conversion of acetate to $\mathrm{H}_{2} / \mathrm{CO}_{2}{ }^{56}$, decreased from $9 \%$ 449 close to $0 \%$, indicating that this pathway was negatively affected by increasing anode 450 potential. This was further supported by the undetectable $\mathrm{H}_{2}$ throughout the whole 451 experiment. Similarly, Methanosaeta concilii, known as acetoclastic methanogens that has 452 ability of interspecies electron transfer with Geobacter species for $\mathrm{CO}_{2}$ reduction into $\mathrm{CH}_{4}$, 453 was diminished from $2.89 \%$ to $0.15 \%$. This significant decrease indicated its inability to 454 survive at high anode potential $+20 \mathrm{mV}$. It has been reported that methanogens require a 455 reductive environment where potential should be less than $-527 \mathrm{mV}$ (vs SHE) for its 456 growth ${ }^{57}$. That simply explained the inhibition of methanogens at $+20 \mathrm{mV}$. In a more recent 457 work ${ }^{58}$, long-term open circuit was found preferable for the growth of methanogens in the 458 cathode of acetogenic microbial electrosynthesis process, which implies the important role 459 of circuit potential on the microbial communities on the electrode. 
460 Furthermore, regarding the competition between exoelectrogens and methanogens, it has

461 been proposed that a special structure of tightly packed aromatic amino acids enabled a

462 long-range electron transport between Geobacter and Methanosaeta ${ }^{15}$. In the

463 methanogenic aggregates, the known role of Geobacter species is converting acetate to

$464 \mathrm{CO}_{2}$ with electrons generating. Through the metallic-like conductive pili, electrons are

465 released and flow to Methanosaeta for $\mathrm{CO}_{2}$ reduction. The final electron sink is methane.

466 The direct interspecies electron transfer way is broken down at positive anode potential

467 since the Methanosaeta is not able to survive/active at high potentials ${ }^{59}$. Thus, when

468 inserting a conductive electrode in the aggregates, the realised electrons from Geobacter

469 metabolism would flow to the electrode instead of being involved in the methane

470 production. In the exoelectrogenic condition, the solid electrode substitutes the

471 Methanosaeta as the electron acceptor.

472 Figure 6 is here.

473 In order to elucidate the difference between the microbial community composition in

474 anodic biofilm (taken from carbon brush), enriched AGS closed to anode electrode and

475 enriched AGS far from anode, significant analysis based on the overall taxa were

476 performed (Figure 6A and B). Distinct consortia were formed in enriched AGS samples

477 and anodic biofilm. Compared to the anodic biofilm, a significant increase in relative

478 abundance of 9 bacterial taxa was observed in the enriched AGS close to carbon brush.

479 Particularly, well-known electrogenic bacteria such as Marinilabiliaceae spp.,

480 Anaerobineaceae spp., and Desulfovibrionales spp. were found significantly increased in

481 the AGS close to carbon brush. Besides, the significantly high abundance of Synergistaceae

482 sp., which was previously demonstrated to be potentially electrogenic, was in accordance 
483 with the electricity generation of Control 1 (MFC after removing granules). Comparatively,

484 no significant difference was observed between AGS far from carbon brush and anodic

485 biofilm, except one strain.

486 To get an additional insight into the difference between two AGS samples (one taken close 487 to carbon brush and the other taken far from carbon brush), the statistical analysis was 488 performed as well (Figure 6C). Clearly, 10 bacterial taxa were observed in significantly 489 higher relative abundance in AGS close to carbon brush compared to the AGS far from 490 carbon brush. The most significant increase was found in Arcobacter butzleri, which was 491 characterized to be capable of transfer electrons from acetate to the electrode ${ }^{60}$. Therefore, 492 the above results strongly implied the AGS close to carbon brush might play more 493 important role in the electricity generation than the AGS far from carbon brush.

\section{Implications}

495 This study demonstrated the proof concept of using intact AGS as biocatalyst in an MFC

496 for simultaneous carbon removal and electricity generation. Compared to the conventional

497 biocatalyst (e.g., domestic wastewater), the AGS has several merits. Firstly, the large 498 surface area of AGS enabled a substantial electrogenic bacterial growth. Secondly, the

499 MFC inoculated with AGS generated much higher current compared to the conventional 500 MFC at same level of substrate. Lastly, the coulombic efficiency improved from $13.62 \%$

501 (before potential control, $1 \mathrm{~g} / \mathrm{L}, 10 \Omega$ ) to $33.82 \%$ (with potential control, $1 \mathrm{~g} / \mathrm{L}$ ) as indicated

502 in Table S2. Although small improvement, the coulombic losses from methanogenic 503 process were diminished. The relatively low value (34\%) might be due to other process

504 such as the cathodic oxygen diffusion or competition from other biological species ${ }^{61,62}$. 
505 Meanwhile, it must be pointed out that though AGS contributed the major part of current

506 generation, the biofilm derived from AGS on the surface of anode electrode is also crucial,

507 as it might play a role of conduit for electron transfer between bulk AGS and electrode.

508 The results indicate that it is possible to boost the current generation of MFC by employing

509 AGS as biocatalyst, but a thin biofilm between ASG and electrode is still needed and may

510 play an important role to efficiently harvest the energy generated by AGS. The special

511 conductive property between AGS and the electrode may open up many other intriguing

512 applications. For instance, the exoelectrogenic AGS could be used as the bed electrodes in

513 METland (wetland plus MET) and other fluidized bed reactor systems ${ }^{63}$.

514 Furthermore, more efforts should be made to further boost the application of AGS for

515 energy recovery and simultaneous wastewater treatment. For instance, the mechanisms of

516 electron transfer among granules should be explored to get better understanding of the

517 system. In that case, how to accelerate the long distance of electron transfer in bacterial

518 community could be identified and addressed well. Another interesting focus could be the

519 studying of layer bacterial distribution in the granules and their involvements in the

520 electron transfer. Further work should also focus on the continuous operation mode and

521 reactor configuration, for example up flow MFC to optimize the settlement of granules for

522 the future potential up scaling, or utilizing gas diffusion air cathode to bringing MFC closer

523 to practical applications ${ }^{64}$.

\section{Supporting Information}

525 Table S1, Figure S1, Figure S2, Figure S3, Figure S4, and Figure S5 as noted in the text.

526 This material is available free of charge via the Internet at http://pubs.acs.org/ 


\section{Author Contributions}

528 YZ, IA and NZ designed the experiments, NZ and LT carried out the research. The

529 manuscript was written through contributions of all authors. YZ is responsible for 530 correspondence.

\section{$531 \quad$ Funding Sources}

532 This research was supported financially by The Danish Council for Independent Research 533 (DFF-1335-00142) and Novo Nordisk Foundation (NNF16OC0021568).

\section{Acknowledgements}

535 The authors would like to acknowledge China Scholarship Council for the financial 536 support. The author would also thank the EliteForsk travel funding supported by Danish

537 Ministry of Education and Research. The authors would also like to acknowledge the 538 technical assistance by Hector Gracia with analytical measurements, and Alexksandra

539 Kulagowska and Colsen (The Netherlands) for offering anaerobic granular sludge.

\section{$540 \quad$ References}

541 1. McCarty, P. L.; Bae, J.; Kim, J., Domestic wastewater treatment as a net energy 542 producer--can this be achieved? Environ Sci Technol 2011, 45, (17), 7100-7106.

543 2. Harnisch, F.; Urban, C., Electrobiorefineries: Unlocking the Synergy of

544 Electrochemical and Microbial Conversions. Angew.Chem-International Edition 2018, 57, 545 (32), 10016-10023. 
546 3. Liu, H.; Ramnarayanan, R.; Logan, B. E., Production of electricity during

547 wastewater treatment using a single chamber microbial fuel cell. Environ Sci Technol 2004,

$548 \quad 38,(7), 2281-2285$.

549 4. Min, B.; Logan, B. E., Continuous electricity generation from domestic wastewater 550 and organic substrates in a flat plate microbial fuel cell. Environ Sci Technol 2004, 38, $551 \quad(21), 5809-5814$.

552 5. Ren, L.; Ahn, Y.; Logan, B. E., A Two-Stage Microbial Fuel Cell and Anaerobic 553 Fluidized Bed Membrane Bioreactor (MFC-AFMBR) System for Effective Domestic 554 Wastewater Treatment. Environ Sci Technol 2014, 48, (7), 4199-4206.

555 6. Wang, Y. K.; Sheng, G. P.; Li, W. W.; Huang, Y. X.; Yu, Y. Y.; Zeng, R. J.; Yu, 556 H. Q., Development of a novel bioelectrochemical membrane reactor for wastewater 557 treatment. Environ Sci Technol 2011, 45, (21), 9256-9261.

558 7. Lovley, D. R., Bug juice: harvesting electricity with microorganisms. Nat Rev 559 Microbiol 2006, 4, (7), 497-508.

560 8. Zhang, Y.; Angelidaki, I., Microbial Electrochemical Systems and Technologies: It

561 Is Time To Report the Capital Costs. Environ Sci Technol 2016, 50, (11), 5432-5433.

562 9. An, J.; Li, N.; Wan, L.; Zhou, L.; Du, Q.; Li, T.; Wang, X., Electric field induced 563 salt precipitation into activated carbon air-cathode causes power decay in microbial fuel 564 cells. Water Res 2017, 123, 369-377.

565 10. Kosaric, N.; Blaszczyk, R.; Orphan, L.; Valladares, J., The characteristics of 566 granukes from upflow anaerobic sludge blanket reactors. Water Res 1990, 24, (12), 14735671477. 
568 11. Lettinga, G.; Pol, L. W. H., UASB-process design for various types of wastewaters.

569 Water Sci Technol 1991, 24, (8), 87-107.

570 12. Schmidt, J. E.; Ahring, B. K., Granular sludge formation in upflow anaerobic sledge

571 blanket (UASB) reactors. Biotechnol Bioeng 1996, 49, (3), 229-246.

572 13. He, Z.; Minteer, S. D.; Angenent, L. T., Electricity generation from artificial 573 wastewater using an upflow microbial fuel cell. Environ Sci Technol 2005, 39, (14), 5262 5745267.

575 14. Morita, M.; Malvankar, N. S.; Franks, A. E.; Summers, Z. M.; Giloteaux, L.; Rotaru, 576 A. E.; Rotaru, C.; Lovley, D. R., Potential for Direct Interspecies Electron Transfer in 577 Methanogenic Wastewater Digester Aggregates. Mbio 2011, 2, (4), 1-8.

578 15. Lovley, D. R., Happy together: microbial communities that hook up to swap 579 electrons. ISME J 2017, 11, (2), 327-336.

580 16. Gell, K., Review of Small Scale, Community Biogas in the Industrialized World.

581 Wageningen University, Netherlands: Community Composting Network. 2008.

582 17. Chong, S.; Sen, T. K.; Kayaalp, A.; Ang, H. M., The performance enhancements of 583 upflow anaerobic sludge blanket (UASB) reactors for domestic sludge treatment--a state584 of-the-art review. Water Res 2012, 46, (11), 3434-3470.

585 18. Zhang, Y.; Angelidaki, I., Recovery of ammonia and sulfate from waste streams 586 and bioenergy production via bipolar bioelectrodialysis. Water Res 2015, 85, 177-184.

587 19. Zhao, N.; Li, X.; Jin, X.; Angelidaki, I.; Zhang, Y., Integrated electrochemical588 biological process as an alternative mean for ammonia monitoring during anaerobic 589 digestion of organic wastes. Chemosphere 2018, 195, 735-741. 
590 20. Zhang, Y.; Noori, J. S.; Angelidaki, I., Simultaneous organic carbon, nutrients

591 removal and energy production in a photomicrobial fuel cell (PFC). Energy Environ. Sci

592 2011, 4, (10), 4340-4346.

593 21. Jin, X.; Zhang, Y.; Li, X.; Zhao, N.; Angelidaki, I., Microbial Electrolytic Capture, 594 Separation and Regeneration of CO2 for Biogas Upgrading. Environ Sci Technol 2017, 51, 595 (16), 9371-9378.

596 22. Zhao, N.; Angelidaki, I.; Zhang, Y., Electricity generation and microbial 597 community in response to short-term changes in stack connection of self-stacked 598 submersible microbial fuel cell powered by glycerol. Water Res 2017, 109, 367-374.

599 23. Zhao, N.; Jiang, Y.; Alvarado-Morales, M.; Treu, L.; Angelidaki, I.; Zhang, Y., 600 Electricity generation and microbial communities in microbial fuel cell powered by 601 macroalgal biomass. Bioelectrochemistry 2018, 123, 145-149.

602 24. Parks, D. H.; Tyson, G. W.; Hugenholtz, P.; Beiko, R. G., STAMP: statistical 603 analysis of taxonomic and functional profiles. Bioinformatics 2014, 30, (21), 3123-3124.

604 25. Jadhav, G. S.; Ghangrekar, M. M., Performance of microbial fuel cell subjected to 605 variation in $\mathrm{pH}$, temperature, external load and substrate concentration. Bioresour Technol 606 2009, 100, (2), 717-723.

607 26. Ren, Z.; Yan, H.; Wang, W.; Mench, M. M.; Regan, J. M., Characterization of 608 Microbial Fuel Cells at Microbially and Electrochemically Meaningful Time scales. 609 Environ Sci Technol 2011, 45, (6), 2435-2441. 
610 27. Song, T.-S.; Yan, Z.-S.; Zhao, Z.-W.; Jiang, H.-L., Removal of organic matter in

611 freshwater sediment by microbial fuel cells at various external resistances. JChem Technol

612 Biotechnol 2010, 1489-1493.

613 28. Jung, S.; Regan, J. M., Influence of external resistance on electrogenesis,

614 methanogenesis, and anode prokaryotic communities in microbial fuel cells. Appl Environ

615 Microbiol 2011, 77, (2), 564-571.

616 29. Butti, S. K.; Velvizhi, G.; Sulonen, M. L. K.; Haavisto, J. M.; Oguz Koroglu, E.;

617 Yusuf Cetinkaya, A.; Singh, S.; Arya, D.; Annie Modestra, J.; Vamsi Krishna, K.; Verma,

618 A.; Ozkaya, B.; Lakaniemi, A.-M.; Puhakka, J. A.; Venkata Mohan, S., Microbial

619 electrochemical technologies with the perspective of harnessing bioenergy: Maneuvering 620 towards upscaling. Renew Sust Energ Rev 2016, 53, 462-476.

621 30. Rotaru, A.-E.; Shrestha, P. M.; Liu, F.; Shrestha, M.; Shrestha, D.; Embree, M.;

622 Zengler, K.; Wardman, C.; Nevin, K. P.; Lovley, D. R., A new model for electron flow

623 during anaerobic digestion: direct interspecies electron transfer to Methanosaeta for the

624 reduction of carbon dioxide to methane. Energy Environ. Sci 2014, 7, (1), 408-415.

625 31. Sleutels, T. H.; Molenaar, S. D.; Heijne, A. T.; Buisman, C. J., Low Substrate 626 Loading Limits Methanogenesis and Leads to High Coulombic Efficiency in 627 Bioelectrochemical Systems. Microorganisms 2016, 4, (1), 1-11.

628 32. Logan, B. E., Exoelectrogenic bacteria that power microbial fuel cells. Nat Rev 629 Microbiol 2009, 7, (5), 375-381.

630 33. Schroder, U., Anodic electron transfer mechanisms in microbial fuel cells and their 631 energy efficiency. Phys Chem Chem Phys 2007, 9, (21), 2619-2629. 
632 34. Hari, A. R.; Katuri, K. P.; Logan, B. E.; Saikaly, P. E., Set anode potentials affect

633 the electron fluxes and microbial community structure in propionate-fed microbial

634 electrolysis cells. Sci Rep 2016, 6, 38690.

635 35. Carmona-Martinez, A. A.; Harnisch, F.; Kuhlicke, U.; Neu, T. R.; Schroder, U., 636 Electron transfer and biofilm formation of Shewanella putrefaciens as function of anode 637 potential. Bioelectrochemistry 2013, 93, 23-29.

638 36. Logan, B. E.; Regan, J. M., Electricity-producing bacterial communities in 639 microbial fuel cells. . Trends Microbiol 2006, 14, (12), 512-518.

640 37. Ren, Z.; Steinberg, L. M.; Regan, J. M., Electricity production and microbial 641 biofilm characterization in cellulose-fed microbial fuel cells. Water Sci Technol 2008, 58, $642(3), 617$.

643 38. Margaria, V.; Tommasi, T.; Pentassuglia, S.; Agostino, V.; Sacco, A.; Armato, C.; 644 Chiodoni, A.; Schilirò, T.; Quaglio, M., Effects of $\mathrm{pH}$ variations on anodic marine consortia 645 in a dual chamber microbial fuel cell. Int J Hydrog Energy 2017, 42, (3), 1820-1829.

646 39. Pevere, A.; Guibaud, G.; Goin, E.; van Hullebusch, E.; Lens, P., Effects of physico647 chemical factors on the viscosity evolution of anaerobic granular sludge. Biochem Eng $J$ $648 \quad 2009,43,(3), 231-238$.

649 40. Quarmby, J.; Forster, C. F., A comparative study of the internal architecture of 650 anaerobic granular sludges. J Chem Technol Biotechnol 1995, 63, (1), 60-68.

651 41. Diaz, E. E.; Stams, A. J.; Amils, R.; Sanz, J. L., Phenotypic properties and microbial 652 diversity of methanogenic granules from a full-scale upflow anaerobic sludge bed reactor 653 treating brewery wastewater. Appl Environ Microbiol 2006, 72, (7), 4942-4949. 
654 42. Kuznar, Z. A.; Elimelech, M., Adhesion kinetics of viable Cryptosporidium parvum 655 oocysts to quartz surfaces. Environ Sci Technol 2004, 38, (24), 6839-6845.

656 43. De Kerchove, A. J.; Elimelech, M., Calcium and magnesium cations enhance the 657 adhesion of motile and nonmotile Pseadomonas aeruginosa on alginate films. Langmuir $6582008,24,(7), 3392-3399$.

659 44. Harris, H. W.; El-Naggar, M. Y.; Bretschger, O.; Ward, M. J.; Romine, M. F.; 660 Obraztsova, A. Y.; Nealson, K. H., Electrokinesis is a microbial behavior that requires 661 extracellular electron transport. Proc Natl Acad Sci USA 2010, 107, (1), 326-331.

662 45. Zhu, X.; Treu, L.; Kougias, P. G.; Campanaro, S.; Angelidaki, I., Characterization 663 of the planktonic microbiome in upflow anaerobic sludge blanket reactors during 664 adaptation of mesophilic methanogenic granules to thermophilic operational conditions. 665 Anaerobe 2017, 46, 69-77.

666 46. Zhang, Y.; Wang, Y.; Angelidaki, I., Alternate switching between microbial fuel 667 cell and microbial electrolysis cell operation as a new method to control $\mathrm{H}_{2} \mathrm{O}_{2}$ level in 668 Bioelectro-Fenton system. . J Power Sources 2015, 291, 108-116.

669 47. Borole, A. P.; Hamilton, C. Y.; Vishnivetskaya, T. A., Enhancement in current 670 density and energy conversion efficiency of 3-dimensional MFC anodes using pre-enriched 671 consortium and continuous supply of electron donors. Bioresour Technol 2011, 102, (8), $672 \quad 5098-5104$.

673 48. Fedorovich, V.; Knighton, M. C.; Pagaling, E.; Ward, F. B.; Free, A.; Goryanin, I., 674 Novel Electrochemically Active Bacterium Phylogenetically Related to Arcobacter 
675 butzleri, Isolated from a Microbial Fuel Cell. Appl. Environ. Microbiol. 2009, 75, (23), $676 \quad 7326-7334$.

677 49. Liu, L.; Tsyganova, O.; Lee, D.-J.; Chang, J.-S.; Wang, A.; Ren, N., Double678 chamber microbial fuel cells started up under room and low temperatures. Int J Hydrog 679 Energy 2013, 38, (35), 15574-15579.

680 50. Sotres, A.; Tey, L.; Bonmati, A.; Vinas, M., Microbial community dynamics in 681 continuous microbial fuel cells fed with synthetic wastewater and pig slurry. 682 Bioelectrochemistry 2016, 111, 70-82.

683 51. Ma, K.; Liu, X. L.; Dong, X. Z., Methanobacterium beijingense sp nov., a. novel 684 methanogen isolated from anaerobic digesters. Int J Syst Evol Microbiol 2005, 55, 325-329.

685 52. Gagliano, M. C.; Ismail, S. B.; Stams, A. J. M.; Plugge, C. M.; Temmink, H.; Van 686 Lier, J. B., Biofilm formation and granule properties in anaerobic digestion at high salinity. 687 Water Res 2017, 121, 61-71.

688 53. Kiely, P. D.; Regan, J. M.; Logan, B. E., The electric picnic: synergistic 689 requirements for exoelectrogenic microbial communities. Curr Opin Biotechnol 2011, 22, $690 \quad(3), 378-385$.

691 54. Logan, B. E.; Rossi, R.; Ragab, A.; Saikaly, P. E., Electroactive microorganisms in 692 bioelectrochemical systems. Nat Rev Microbiol 2019, 17, (5), 307-319.

693 55. Chae, K. J.; Choi, M. J.; Lee, J. W.; Kim, K. Y.; Kim, I. S., Effect of different 694 substrates on the performance, bacterial diversity, and bacterial viability in microbial fuel 695 cells. Bioresour Technol 2009, 100, (14), 3518-3525. 
696 56. Ahlert, S.; Zimmermann, R.; Ebling, J.; Konig, H., Analysis of propionate-

697 degrading consortia from agricultural biogas plants. Microbiologyopen 2016, 5, (6), 10276981037.

699 57. Lange, M.; Ahring, B. K., A comprehensive study into the molecular methodology 700 and molecular biology of methanogenic Archaea. Fems Microbiol Rev 2001, 25, (5), 553701571.

702 58. Mateos, R.; Escapa, A.; San-Martín, M. I.; Wever, H. D.; Sotres, A.; Pant, D., Long703 term open circuit microbial electrosynthesis system promotes methanogenesis. J Eng Chem $704 \mathbf{2 0 2 0}, 41,3-6$.

705 59. Jadhav, D. A.; Chendake, A. D.; Schievano, A.; Pant, D., Suppressing methanogens 706 and enriching electrogens in bioelectrochemical systems. Bioresour Technol 2019, 277, $707 \quad 148-156$.

708 60. Toh, H.; Sharma, V. K.; Oshima, K.; Kondo, S.; Hattori, M.; Ward, F. B.; Free, A.; 709 Taylor, T. D., Complete genome sequences of Arcobacter butzleri ED-1 and Arcobacter 710 sp. strain L, both isolated from a microbial fuel cell. J Bacteriol 2011, 193, (22), 64117116412.

712 61. Ahn, Y.; Logan, B. E., Domestic wastewater treatment using multi-electrode 713 continuous flow MFCs with a separator electrode assembly design. Appl Microbiol 714 Biotechnol 2013, 97, (1), 409-416.

715 62. Kim, K. Y.; Yang, W.; Logan, B. E., Impact of electrode configurations on retention 716 time and domestic wastewater treatment efficiency using microbial fuel cells. Water Res 717 2015, 80, 41-46. 
718 63. Ramírez-Vargas, C.; Prado, A.; Arias, C.; Carvalho, P.; Esteve-Núñez, A.; Brix,

719 H., Microbial Electrochemical Technologies for Wastewater Treatment: Principles and

720 Evolution from Microbial Fuel Cells to Bioelectrochemical-Based Constructed Wetlands.

721 Water 2018, 10, (9).

722 64. Rossi, R.; Jones, D.; Myung, J.; Zikmund, E.; Yang, W.; Gallego, Y. A.; Pant, D.;

723 Evans, P. J.; Page, M. A.; Cropek, D. M.; Logan, B. E., Evaluating a multi-panel air cathode

724 through electrochemical and biotic tests. Water Res 2019, 148, 51-59.

725 


\section{$726 \quad$ List of figure captions}

727 Figure 1 Current density (A), TCOD removal (B) and biogas production rate and methane

728 yield (C) over time at different external resistance and different acetate concentrations. Red

729 line and green line refer to the performance of R-10 ohm, $1500 \mathrm{mg} / \mathrm{L}$ in Strategy 1 and

730 Strategy 2 , respectively.

731 Figure 2 Current density (A), acetate concentrations (B) and average biogas production rate

732 and methane yield (C) with time in different reactors. Control 1: MFC with only carbon

733 brush (after potential control and moving granules out).

734 Figure 3 The maximum current density and COD removal rate coefficient at varied $\mathrm{pH}$

735 conditions. AGS-MFC: MFC after potential control; Control 3: MFC inoculated with

736 domestic wastewater.

737 Figure 4 SEM image of the surface structure of single GAS after anodic potential 738 control:(A) an intact granule; (B) high-resolution of SEM image of granular surface

739 showing the massive microbial colonization; (C) showing the rod-shape microbes aligned

740 on the side of deep channels. (D) Energy-dispersive X-ray (EDS) results of AGS before

741 and after strategy 3. (E) Particle size distribution of raw AGS and cultivated AGS after

742 strategy 3.

743 Figure 5 Microbial community compositions in raw AGS (G1), and enriched AGS after

744 anode potential control and close to carbon brush (G2), enriched AGS far from carbon

745 brush (G3), and biofilm on carbon brush (Biofilm). Relative abundance (\%) and folds

746 change were reported in (A) and (B), respectively. Group 1: the taxa increased in relative 
747 abundance after anode potential control. Group 2: the taxa decreased in relative abundance 748 after anode potential control.

749 Figure 6 OTUs that changed significantly $(\mathrm{p}<0.05)$ in the comparison between G2

750 (enriched AGS taken from close to carbon brush after strategy 3) and Biofilm (A), between

751 G3 (enriched AGS taken far from carbon brush after strategy 3) and Biofilm (B), and 752 between G3 and G2 (C), respectively.

753 

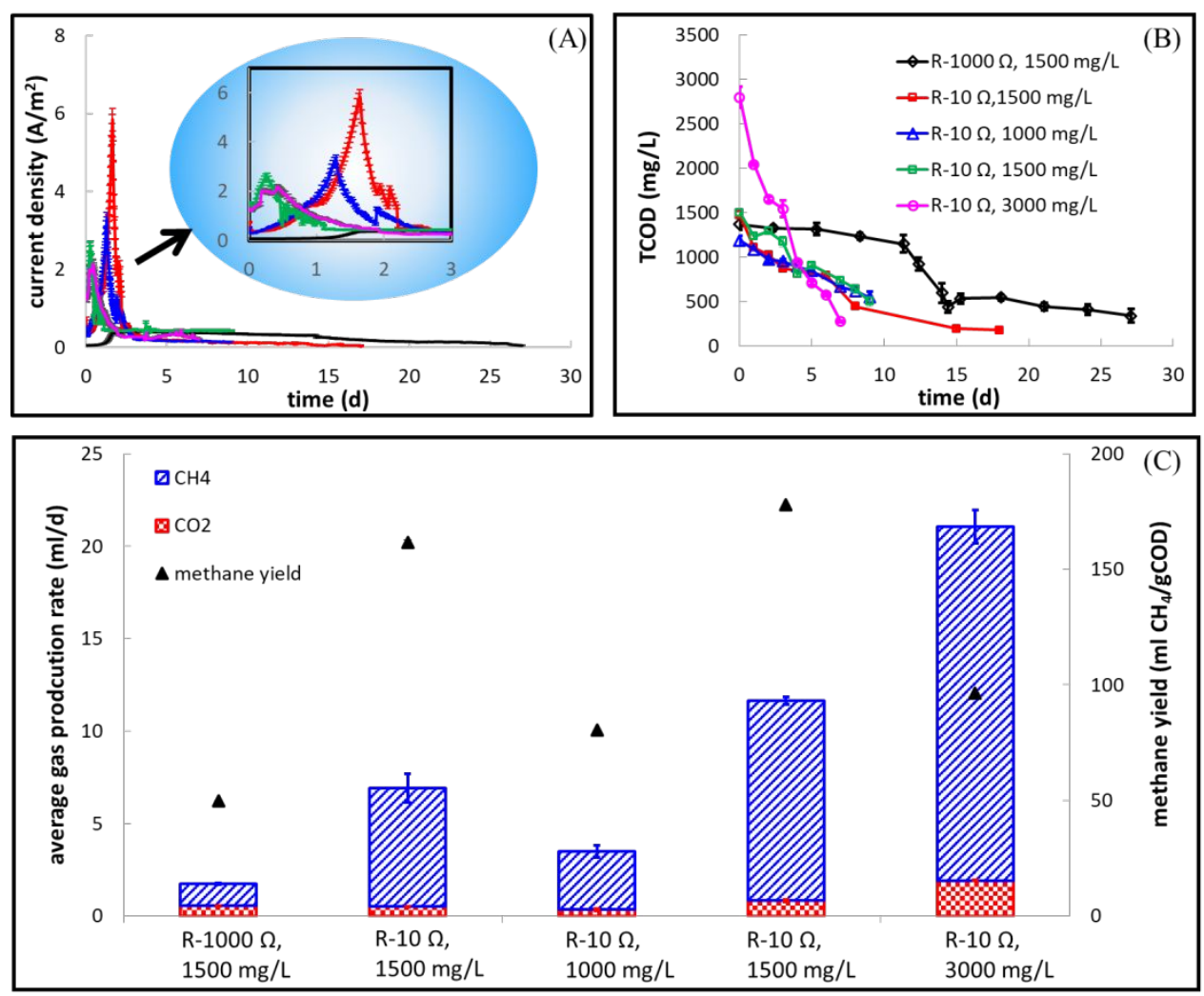

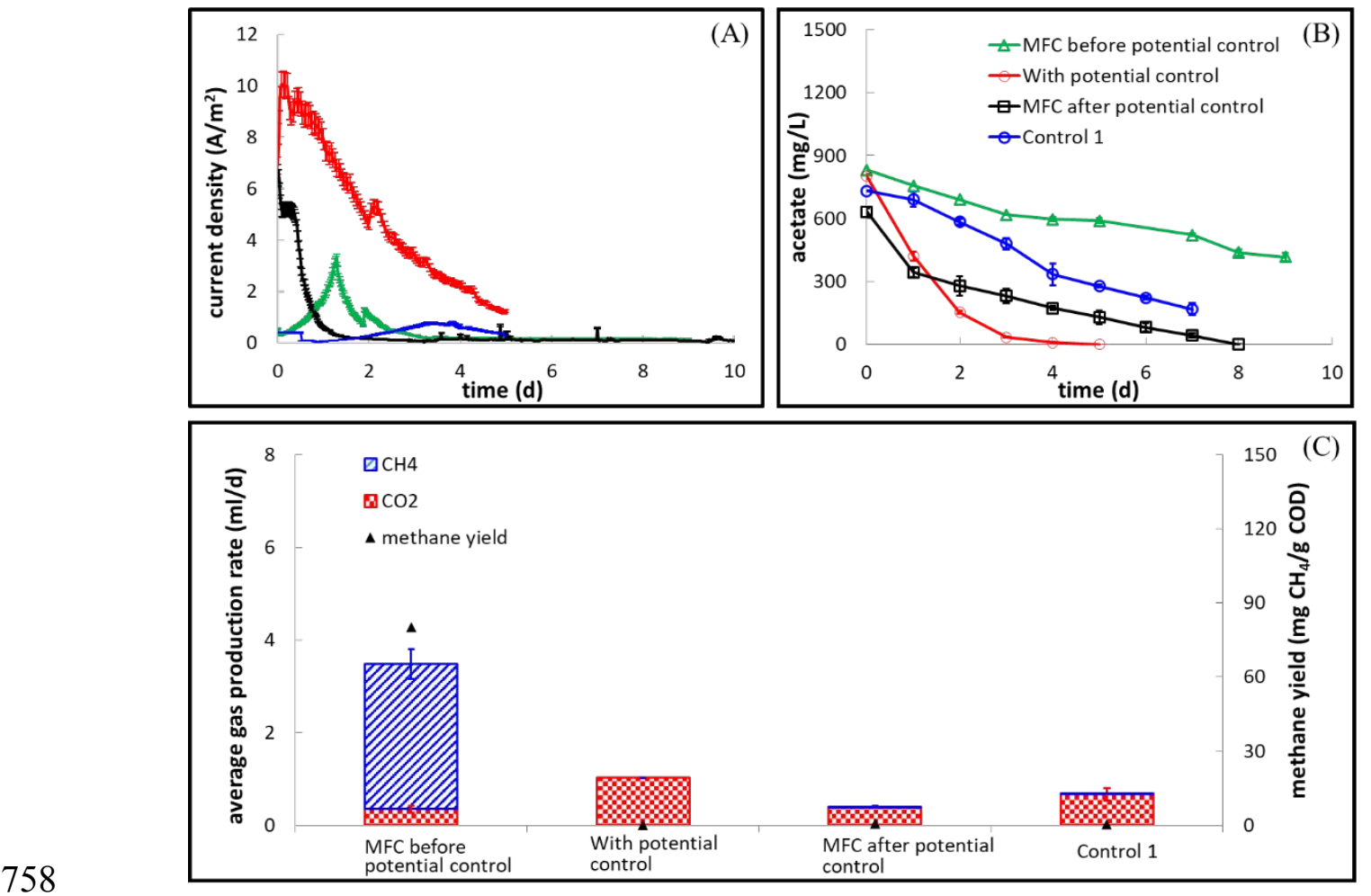


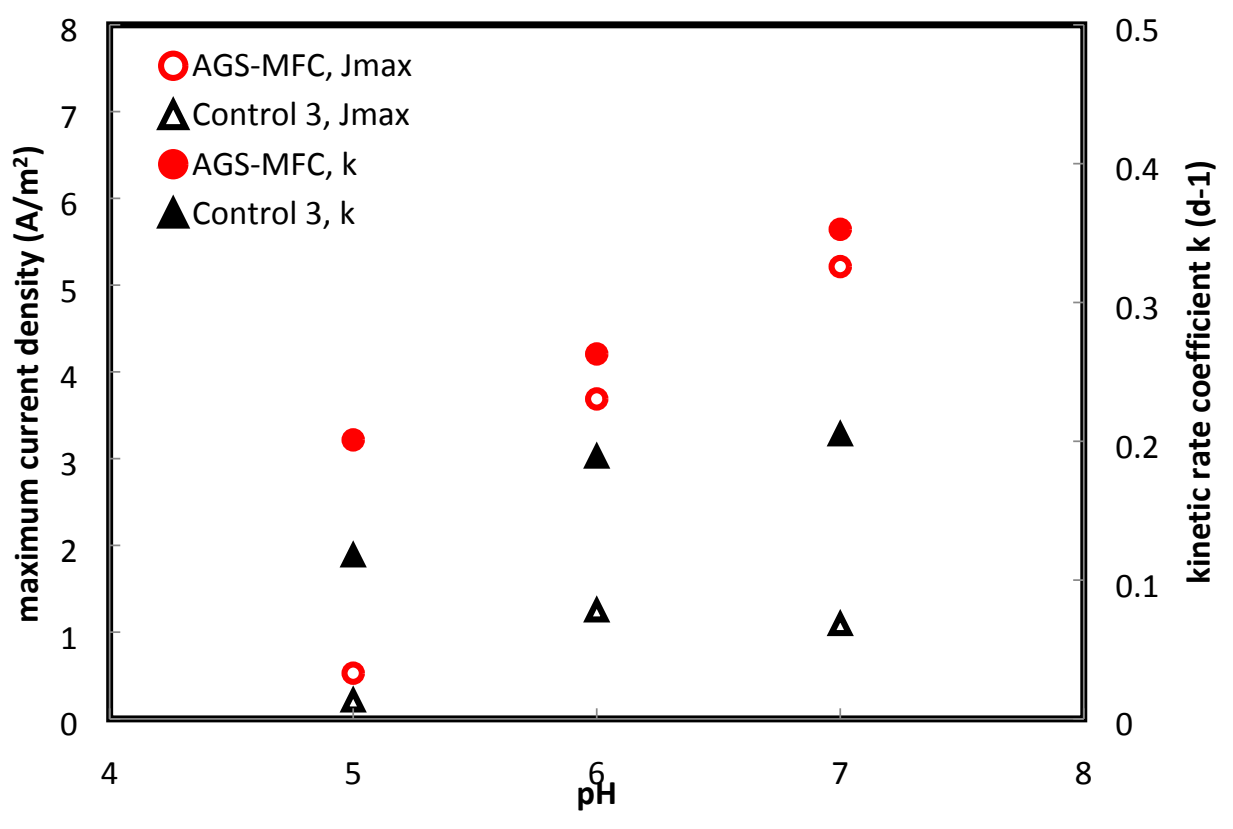



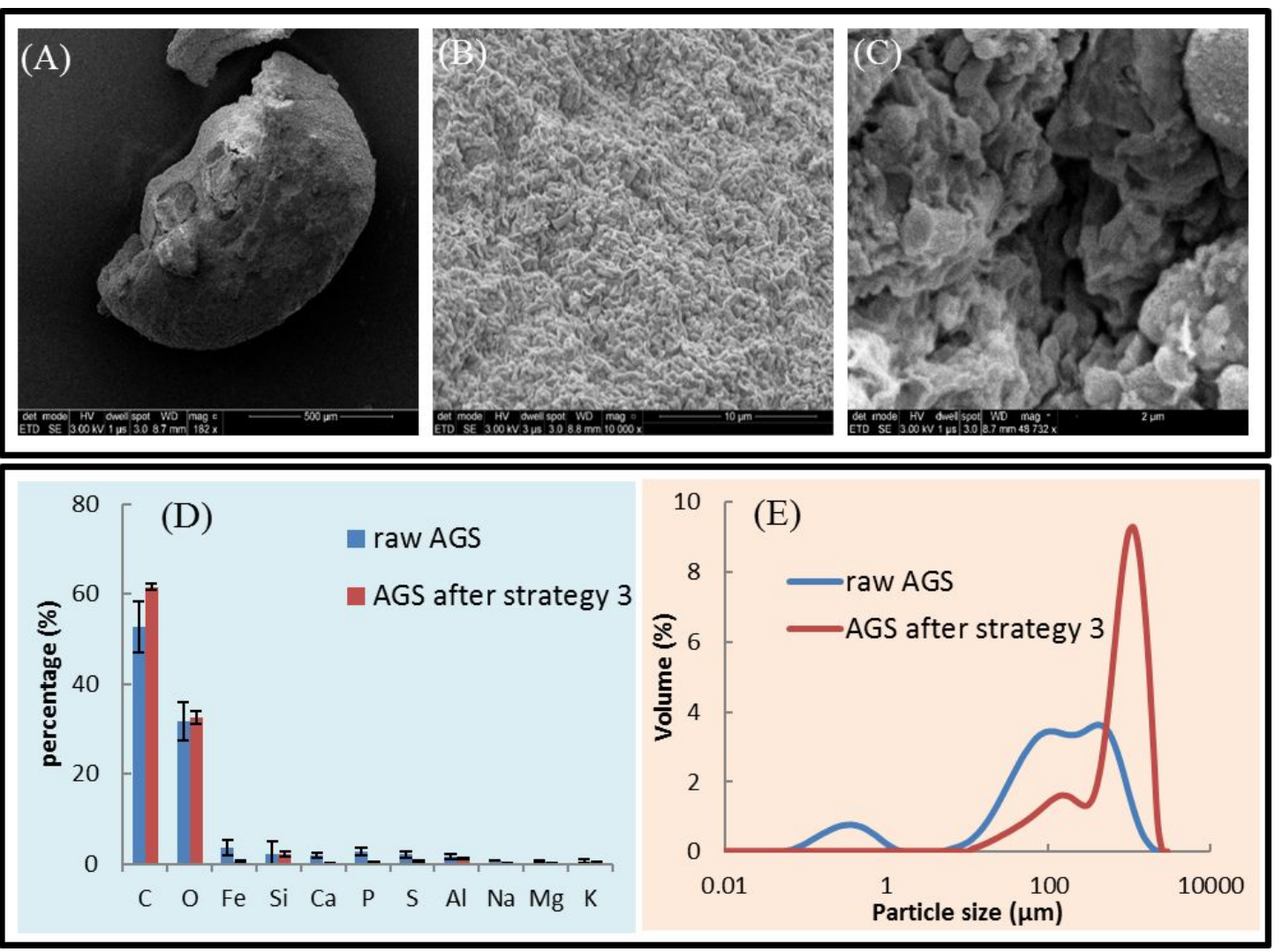


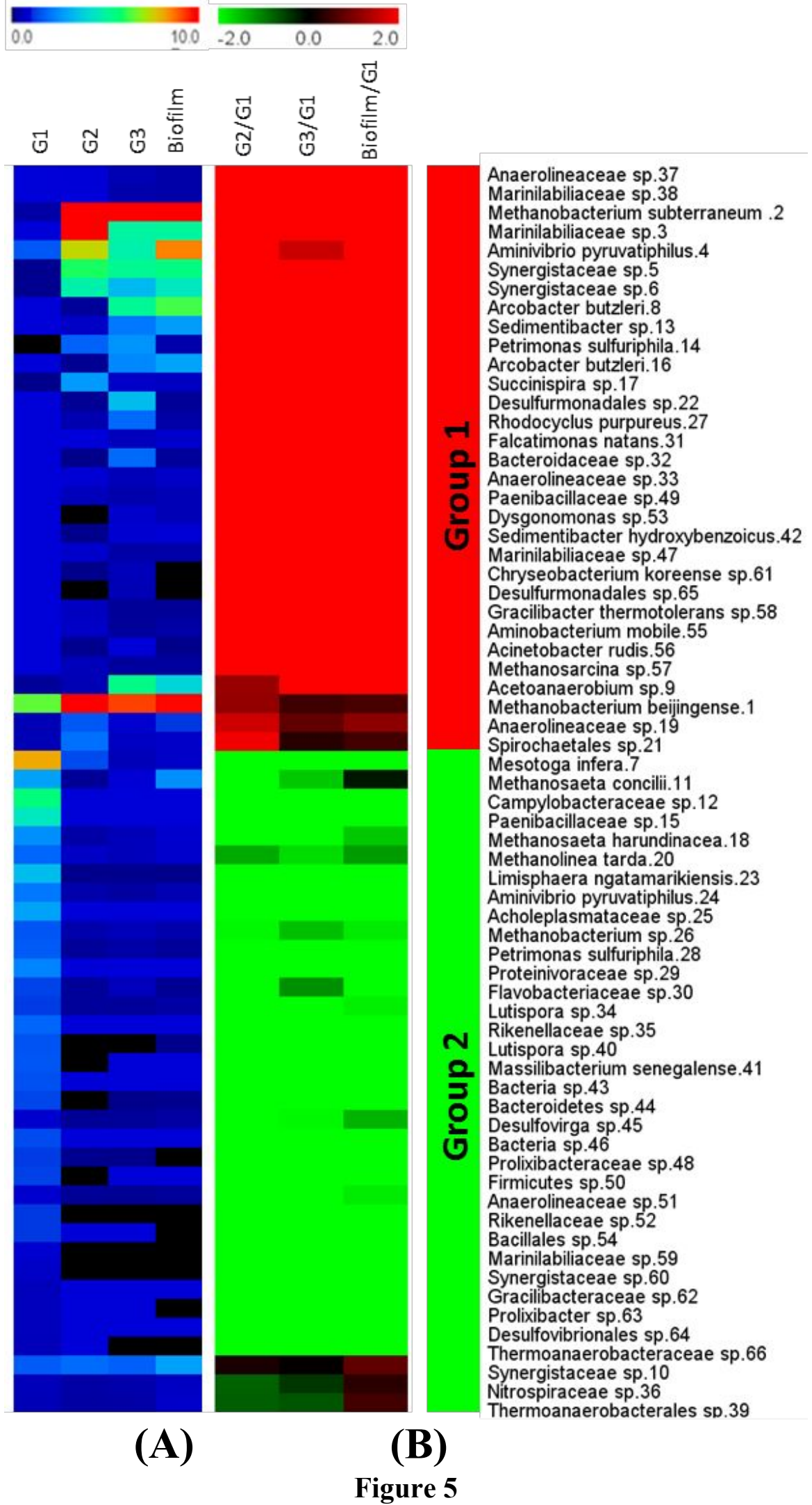


(A)

Anaerolineaceae sp.19
Petrimonas sulfuriphila.14
Synergistaceae.10
Mathanosaeta harundinacea.18
Mesotoga infera.7
Bacteroidaceae sp.32
Succinispira sp.17
Prolixibacter sp.63
Anaerolineaceae sp.51
Limisphaera ngatamarikiensis.23
Desulfovibrionales sp.64
Bacillales sp.54
Anaerolineaceae sp.33
Marinilabiliaceae sp.47|
Firmicutes sp.50
0.0
Mean proportion (\%)

$95 \%$ confidence intervals

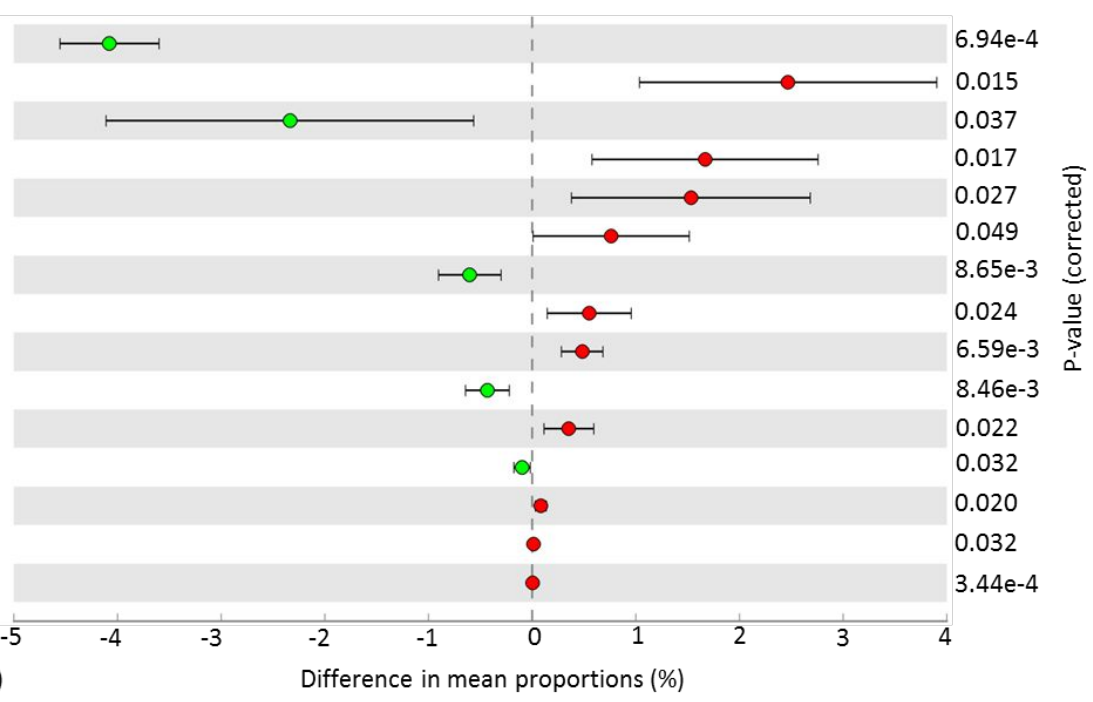

$95 \%$ confidence intervals

(B)

Aminobacterium mobile.55

0.040

0.0
Mean proportion $(\%)$

$-0.03$

771

\section{(C)}

Arcobacter butzleri.8

Marinilabiliaceae sp. 3

Anaerolineaceae sp.19

Petrimonas sulfuriphila.14 는

Synergistaceae.10 $\boldsymbol{\Gamma}$

Mesotoga infera.7 $\mathbf{b}$

Aminivibrio pyruvatiphilus. 4 L

Bacteroidaceae sp.32

Anaerolineaceae sp.51h

Prolixibacter sp.63 $\mathrm{h}$

Desulfovibrionales sp.64 b

Marinilabiliaceae sp.47|

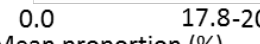

Mean proportion (\%)

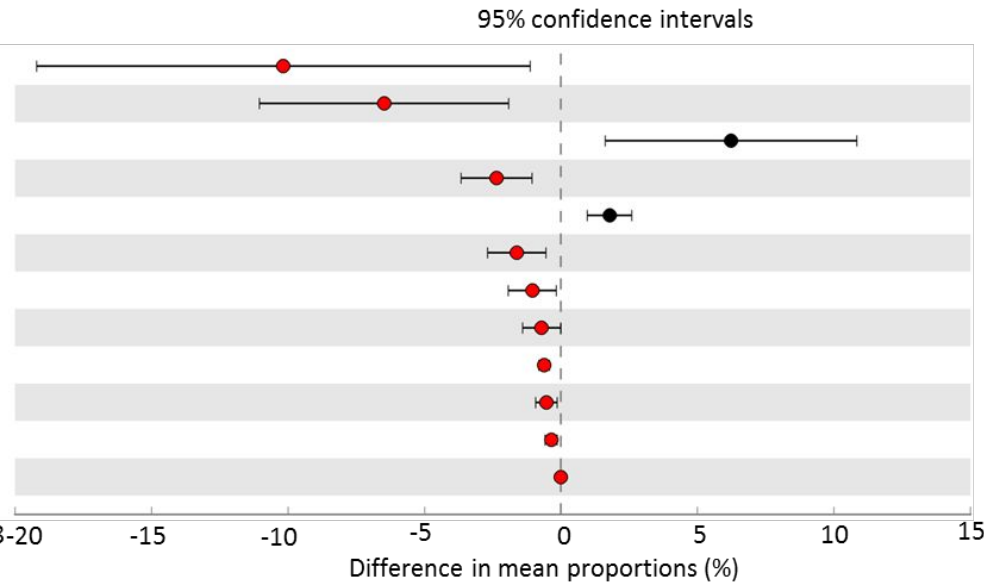

G2
0.039

0.020

0.028

$8.35 \mathrm{e}-3$ वे

0.010

0.014

0.030

0.049

$1.38 \mathrm{e}-3$

0.019

0.011

0.034 


\section{TOC Art}

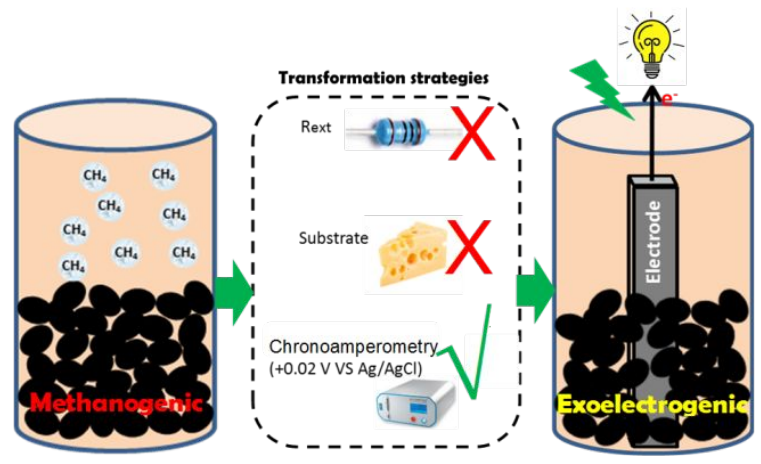

